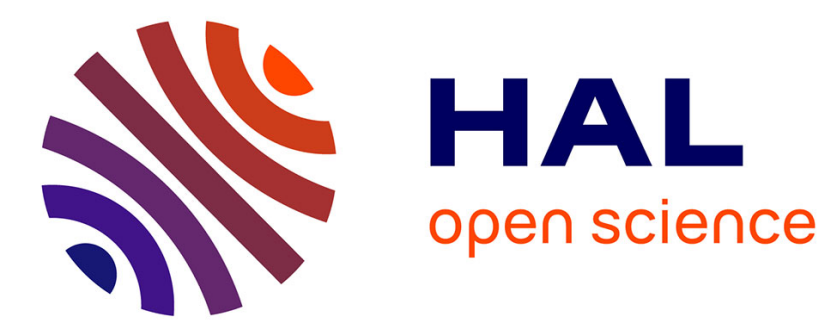

\title{
Seismic anisotropy reveals the long route of the slab through the western-central Mediterranean mantle
}

Francesco Pio Lucente, Lucia Margheriti, Claudia Piromallo, Guilhem Barruol

\section{To cite this version:}

Francesco Pio Lucente, Lucia Margheriti, Claudia Piromallo, Guilhem Barruol. Seismic anisotropy reveals the long route of the slab through the western-central Mediterranean mantle. Earth and Planetary Science Letters, 2006, 241 (3-4), pp.517 - 529. 10.1016/j.epsl.2005.10.041 . hal-01389115

\section{HAL Id: hal-01389115 \\ https://hal.univ-reunion.fr/hal-01389115}

Submitted on 28 Oct 2016

HAL is a multi-disciplinary open access archive for the deposit and dissemination of scientific research documents, whether they are published or not. The documents may come from teaching and research institutions in France or abroad, or from public or private research centers.
L'archive ouverte pluridisciplinaire HAL, est destinée au dépôt et à la diffusion de documents scientifiques de niveau recherche, publiés ou non, émanant des établissements d'enseignement et de recherche français ou étrangers, des laboratoires publics ou privés. 


\title{
Seismic anisotropy reveals the long route of the slab through the western-central Mediterranean mantle
}

\author{
Francesco Pio Lucente ${ }^{\mathrm{a}, *}$, Lucia Margheriti ${ }^{\mathrm{a}, 1}$, Claudia Piromallo ${ }^{\mathrm{a}, 2}$, Guilhem Barruol ${ }^{\mathrm{b}, 3}$

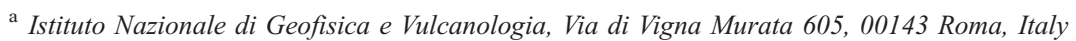 \\ b Observatoire Géodésique de Tahiti, Laboratoire Terre-Océan, Université de la Polynésie Française, BP 6570, 98702 Faaa Aeroport, Tahiti, \\ Polynésie Française
}

Received 9 November 2004; received in revised form 7 July 2005; accepted 1 October 2005

Available online 6 January 2006

Editor: V. Courtillot

\begin{abstract}
In the south-eastern corner of the Tyrrhenian basin, in the central Mediterranean Sea, a tight alignment of earthquakes along a well-defined Benioff zone marks one of the narrowest active trenches worldwide, where one of the last fragment of the former Tethys ocean is consumed. Seismic tomography furnishes snapshot images of the present-day position of this slab, and seismic anisotropy allows to reconstruct the past kinematics of the subduction process. Using seismic anisotropy fast directions as a proxy for the present and past mantle flow, we look backward for the seismic traces of the slab motion through the western-central Mediterranean mantle, from the starting locus of subduction toward its present day position. The result of combining independent data sets provides a coherent pattern of anisotropy that illustrates an example of slab rollback from its initiation point to its presentday position.
\end{abstract}

Keywords: Seismic anisotropy; Tyrrhenian basin; Slab motion; Rollback; Mantle

\section{Introduction}

The Tyrrhenian basin (Fig. 1) is part of the tectonic boundary between two slowly converging macroplates, Eurasia and Africa [1,2]. The protracted (from Late Cretaceous) collision between the two continental

\footnotetext{
* Corresponding author. Tel.: +39 0651860486; fax: +39 0651860507.

E-mail addresses: lucente@ingv.it (F.P. Lucente), margheriti@ingv.it (L. Margheriti), piromallo@ingv.it (C. Piromallo), barruol@upf.pf (G. Barruol).

${ }^{1}$ Tel.: +39 0651860519; fax: +390651860507.

${ }^{2}$ Tel.: +39 0651860479; fax: +390651860507.

${ }^{3}$ Tel.: +689 803884 (GMT-10); fax: +689 803842 .
}

macro-plates led to the existence of a wide belt of crustal deformation that masks the actual plate margins, resulting in a puzzling pattern of extensional basins of newly formed oceanic crust, compressional arcuate mountain belts, and subduction zones of remnant oceanic lithosphere [3-5]. In the general context of the $\mathrm{N}-$ $\mathrm{S}$ convergence of Europe and Africa, which acts as background force shaping the Mediterranean area, the existence of differently oriented tectonic and physiographic features and especially of large extensional areas is somewhat enigmatic. Moreover, the time scale of formation of some of these tectonic features, like the Tyrrhenian basin and the Apennines, is by far faster than the rate of convergence between Africa and Eurasia $[6,7]$, suggesting a predominant role played by 


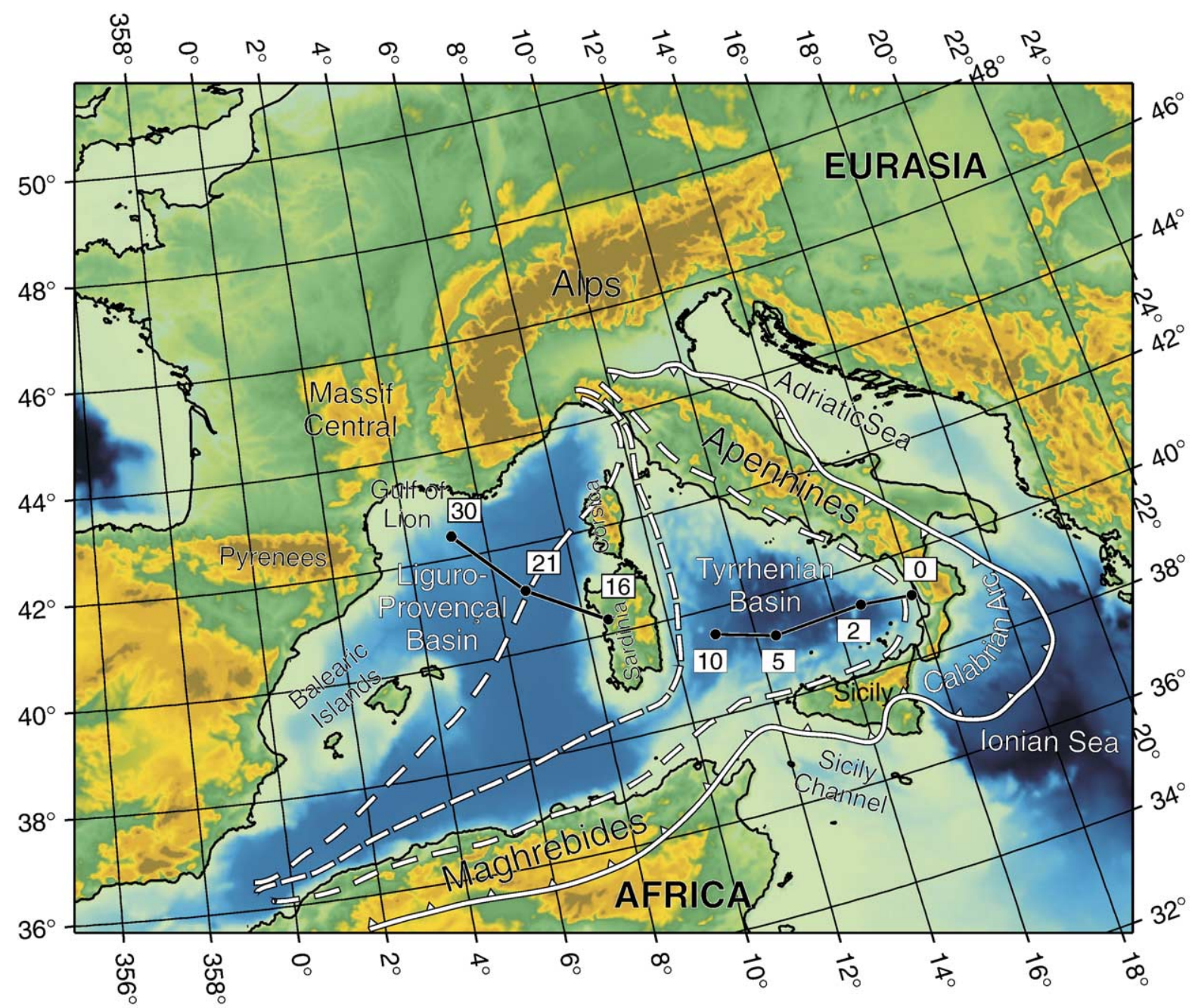

Fig. 1. Topographic map of the western-central Mediterranean region showing a reconstruction of the subduction evolution in the last 30 My. Continuous white line with the sawtooth pattern represents the present-day location of the convergent boundary. The sawteeth point in the direction of subduction or underthrusting. Dashed white lines approximately indicate past positions of the trench at three stages of its migration, according to the paleotectonic reconstruction by [7,8]. The displacement trajectories related to back-arc extension (redrawn from [10]) are displayed by the black line (numbers are million years).

forces independent of the Africa-Europe collision. Reconstructing the geodynamic evolution of the western-central Mediterranean has been therefore challenging for various authors in the past decades [4]. From the paper by Malinverno and Ryan [6], subduction zone retreat and associated arc migration is taken into account as a force driving extension of basins and building of the tightly curved orogenic belt in the western-central Mediterranean area. The opening of the western-central Mediterranean (Fig. 1) mainly took place in the last $30 \mathrm{Ma}$, with genesis of irregular basins whose age becomes younger from west to east. These extensional basins were closely related in time and space to the back-arc region of the eastward retreating Apennines-Maghrebides subduction zone $[7,8]$. At present, subduction in the western-central Mediterranean is indicated by the occurrence of deep seismicity beneath the southern Tyrrhenian basin; hypocenters are distributed along a continuous 200$\mathrm{km}$-wide Benioff zone, dipping to the NW at about $70^{\circ}$ down to a depth of about $500 \mathrm{~km}$ (Fig. 2) [9]. Paleogeographic reconstructions agree in considering the narrow slab below the Calabrian Arc as a remnant of a once wider subduction zone, responsible for the back-arc opening of the Liguro-Provençal and the Tyrrhenian basins, during the last 30 My $[3,6-8,10]$. Recent tomographic investigations of the mantle beneath the Italian Peninsula [11,12] strongly support 


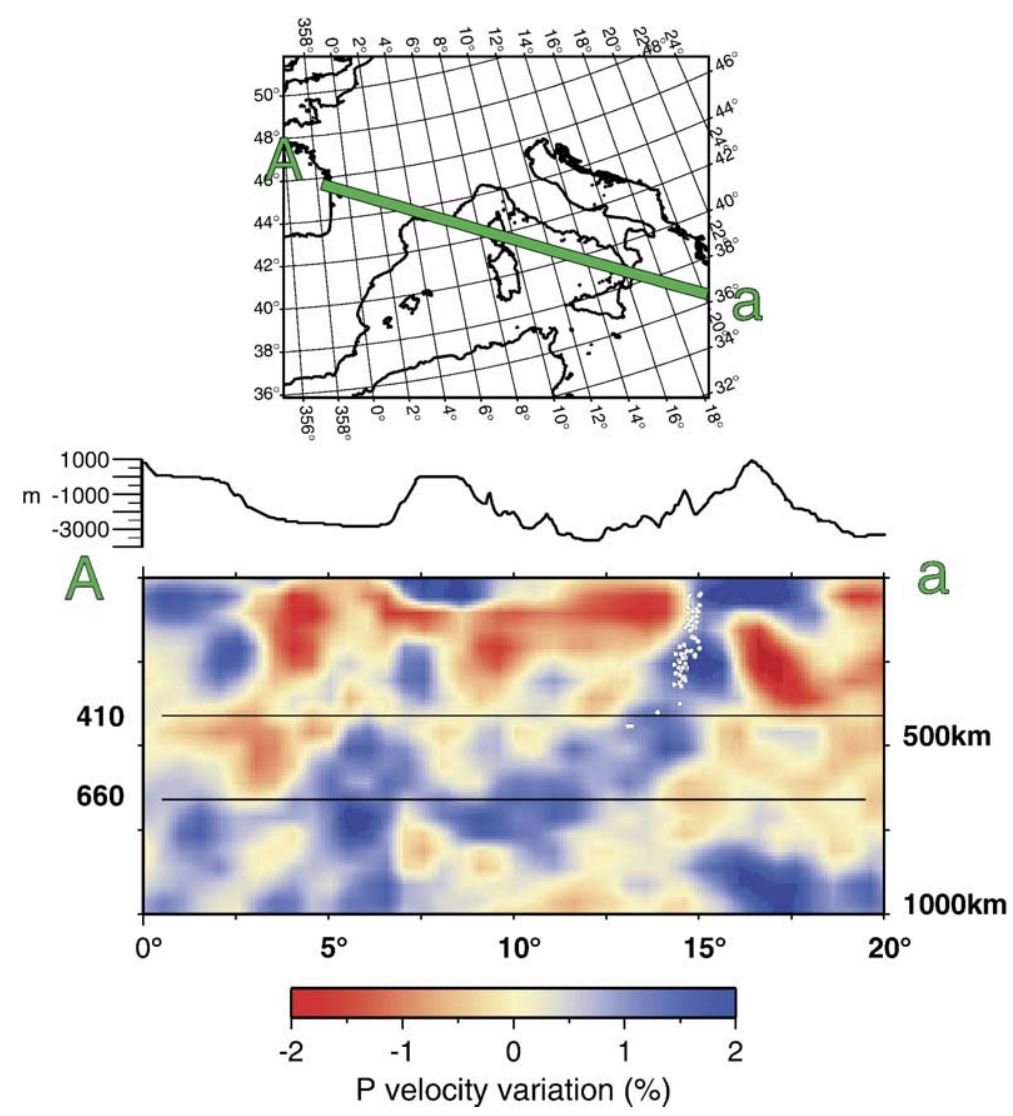

Fig. 2. Tomographic section across the present-day southern Tyrrhenian slab, from the Gulf of Lion to Calabria [12]. Horizontal scale is in degrees along the great circle through the section, vertical scale is in $\mathrm{km}$ (no vertical exaggeration). The topographic profile is superimposed (50 $\times$ vertical exaggeration). White dots are intermediate and deep earthquakes within $30 \mathrm{~km}$ of the cross section plane (from [9]).

these earlier paleogeographic reconstructions. A crosssection from Calabria to the Gulf of Lion (Fig. 2) evidences an almost continuous high-velocity body extending from the surface below Calabria, with a NW dip of $70-80^{\circ}$, and then turning horizontally in the transition zone. The estimated total length of the high-velocity zone, interpreted as subducted lithosphere is $\sim 1200-1400 \mathrm{~km}$, measured from the base of the lithosphere and including its lowermost flat portion [10]. It is noteworthy that this is a robust feature, as all tomographic studies performed in this region, using different data sets and techniques [1113], obtained velocity models similar in both geometry and total length for the Tyrrhenian slab. According to the various paleogeographic reconstructions and the tomographic images (Fig. 2), the Tyrrhenian slab fragment would have rolled back for $800-1000 \mathrm{~km}$, from the present-day south-east coasts of Spain and France toward its current position in the southern Tyrrhenian.

In this paper, we present a compilation of published and new upper mantle anisotropy measurements along the possible route of the slab through the westerncentral Mediterranean mantle, from the starting locus of the subduction process to its present day position, together with tomographic images of the upper mantle velocity structure, to demonstrate how the retrograde motion of the sinking slab would have driven a regional flow in the mantle and influenced the evolution of the western-central-Mediterranean.

\section{Anisotropy and geodynamics in western-central Mediterranean}

It is broadly accepted that elastic anisotropy in the Earth's interior is related to the preferred orientation of minerals in the flow or deformation direction. The alignment of the crystals symmetry axes affects the seismic wave propagation, causing differential velocity, scattering and birefringence. For the upper mantle, seismic anisotropy primarily results from elastic anisotropy of olivine, which is the main and the most anisotropic upper mantle mineral [14], and from preferred 
orientation of its crystals induced by tectonic flow $[15,16]$. Thus, quantifying seismic anisotropy in the upper mantle may help to image the past-and therefore "frozen-in"-or the present-day mantle flows. Upper mantle seismic anisotropy is commonly measured by using the splitting of teleseismic shear waves: a polarized shear wave crossing an anisotropic medium is split into two perpendicularly polarized waves that propagate at different velocities, producing two measurable quantities, the time delay $\delta t$ between fast and slow polarized $S$ and the azimuth $\phi$ of the fast wave polarization plane. Petrophysical studies have shown that $\phi$ is a proxy for the orientation of the [100] axis of olivine assumed to be statistically parallel to the flow direction [14]. The delay time depends on the medium intrinsic anisotropy, on the thickness of the anisotropic layer, on the orientation of the ray path with respect to the elastic matrix of the anisotropic medium, and on the vertical coherence of the mantle fabric. The direct relationships between splitting parameters and the crystallographic fabric of mantle rocks have made shear wave splitting a useful tool to investigate upper mantle deformation. During the past two decades, splitting data have confirmed many predictions of mantle flow from plate tectonics [16-18], especially in relatively simple tectonic environments. Interestingly, mantle petrophysics has also shown that mantle fabrics can be preserved for very long periods of time, such as billion of years in the case of craton's roots (e.g. [19]), as no subsequent thermal or tectonic events have affected the pre-existing fabric. Combining the present-day upper mantle structure provided by seismic tomography with the flow history derived by seismic anisotropy can be therefore a fruitful way to reconstruct the geodynamic evolution of the considered region.

We gather more than 500 seismic anisotropy measurements resulting from analysis of core-phases $S K S$, $S K K S$ and $P K S$ at 106 stations located in the westerncentral Mediterranean area from the Pyrenees and Massif Central in the north-west, to the Calabrian arc in the south-east (Fig. 3). This compilation of shear wave splitting measurements is mainly derived from previous studies limited to smaller areas and to temporary experiments (red bars in Fig. 3 [20-25]). The reference papers associated with the data are presented in the inset Fig. 3. This data set includes only good quality, non-null, single event measurements computed using the Silver and Chan [26] algorithm. We added some new unpublished data (blue bars in Fig. 3) which consist of 30 high quality splitting measurements resulting from the analysis of the 1999-2003 recordings available at MAHO station, in the Balearic Islands, and of the
2004 recordings at six seismic stations (INGV networks) located in southern Italy (Table 1). All the new data are from $M>6.0$ earthquakes with epicentral distance between $88^{\circ}$ and $102^{\circ}$. These new measurements provide anisotropic parameters in the otherwise unsampled Liguro-Provençal basin (MAHO) and also improve the coverage above the present day location of the slab, in the southern Tyrrhenian.

We choose to project each individual splitting measurement at the $150 \mathrm{~km}$ depth piercing point along the incoming ray (Fig. 3), in order to separate the measurements from different back azimuths and incidence angles [27]. The choice of this particular depth for the measurements projection is mainly based on considerations involving the variations of the anisotropy parameters and the amplitudes of the Fresnel zones at various depths for the analyzed $S K S$ waves periods (see [23]). The delay times in the whole area range from 0.5 to $2.7 \mathrm{~s}$, with an average value of about $1.5 \mathrm{~s}$, which corresponds to an anisotropic layer about 150 $200 \mathrm{~km}$ thick with about 5\% anisotropy [15]. Such deformation is probably underestimated at some places since petrophysical analyses of upper mantle nodules brought up at the surface by recent volcanism occurring in central Italy [28] show strong olivine preferred orientations generating strong shear wave anisotropies (Vs anisotropy from $7.3 \%$ to $13.4 \%$ ). Due to the absence of ocean bottom stations in the studied area, the coverage is uneven, leaving the oceanic basins (LiguroProvençal and Tyrrhenian) unsampled. Nevertheless, the regions crucial to our interpretation are fairly sampled, thanks to islands stations, and we do not expect strong and sudden variations inside the basins, which are likely stable environments.

The ensemble of the fast direction bars on the map (Fig. 3) provides a comprehensive picture of the mantle deformation in the western-central Mediterranean. In the last $30 \mathrm{My}$ time frame, the geodynamics of this region has been dominated by a succession of two main fast and short rifting episodes (accompanied by the creation of new small oceanic basins) and drifting phases (with progressive migration of continental lithosphere blocks) $[7,8,10]$, driven by the retreat of the Apennines-Maghrebides subduction zone (cf. Fig. 1).

In the following, we compare the main phases of the Tertiary tectonic evolution in the western-central Mediterranean area $[6-8,10]$ with the observed seismic anisotropy along the trajectory that the Tyrrhenian slab is supposed to have drawn during its rollback motion. Moving from West to East we identify three main areas characterized by consistent anisotropy patterns and we 


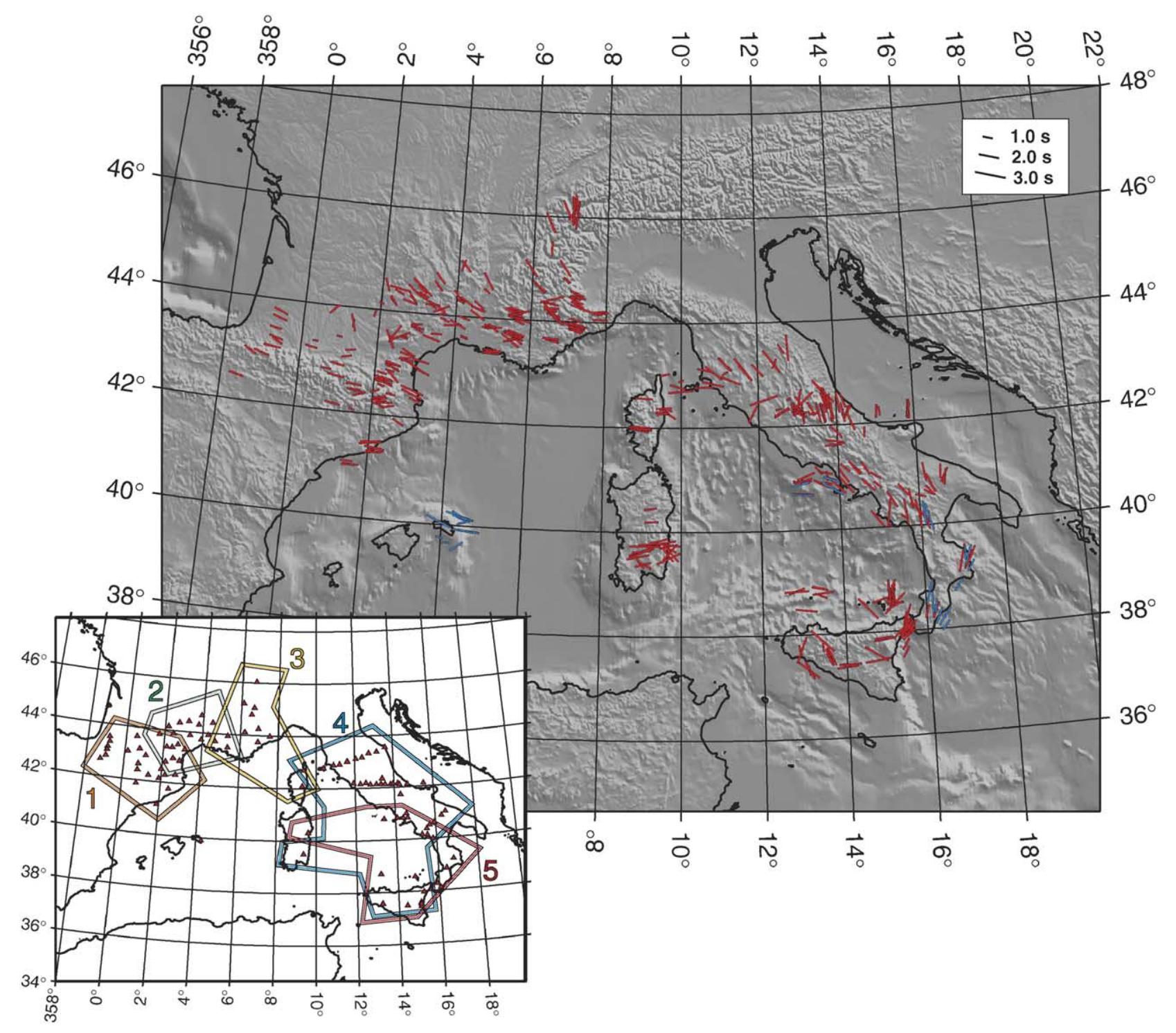

Fig. 3. Compilation of shear wave splitting measurements superimposed on a shaded relief map of the western-central Mediterranean. Measurements are represented by solid red bars (previously published) and solid blue bars (new ones) oriented parallel to the fast polarization directions, with length proportional to the delay time. Each measurement is plotted at the surface projection of the $150 \mathrm{~km}$ depth seismic ray piercing point. The inset shows the distribution of seismic stations used in this study and the related references of the previously published anisotropy measurements: 1: [20,21], 2: [22], 3: [25], 4: [23], 5: [24]. 
Table 1

New splitting measurements

\begin{tabular}{|c|c|c|c|c|c|c|c|c|c|c|c|}
\hline \multicolumn{3}{|l|}{ Station } & \multicolumn{5}{|l|}{ Earthquake } & \multicolumn{4}{|c|}{ Anisotropic parameters } \\
\hline Code & Lat & Lon & Date & Time & Mag & Delta $\left(^{\circ}\right)$ & $\operatorname{Baz}\left({ }^{\circ}\right)$ & $\phi\left({ }^{\circ}\right)$ & $\Delta \phi\left(^{\circ}\right)$ & $\delta \tau(\mathrm{s})$ & $\Delta \delta \tau(\mathrm{s})$ \\
\hline MAHO & 39.8959 & 4.2665 & $14 / 08 / 1999$ & $00: 16: 52$ & 6.5 & 102 & 88 & -85 & 2 & 2.5 & 0.5 \\
\hline MAHO & 39.8959 & 4.2665 & $28 / 012000$ & $14: 21: 07$ & 6.6 & 91 & 26 & -74 & 7 & 2.7 & 1.4 \\
\hline MAHO & 39.8959 & 4.2665 & $04 / 06 / 2000$ & $16: 28: 26$ & 6.8 & 99 & 89 & -85 & 8 & 2.7 & 1.0 \\
\hline MAHO & 39.8959 & 4.2665 & $07 / 06 / 2000$ & $23: 45: 26$ & 6.5 & 99 & 89 & -79 & 8 & 1.3 & 0.5 \\
\hline MAHO & 39.8959 & 4.2665 & $18 / 06 / 2000$ & $14: 44: 13$ & 6.8 & 101 & 99 & 13 & 20 & 1.4 & 0.7 \\
\hline MAHO & 39.8959 & 4.2665 & $24 / 03 / 2001$ & $06: 27: 53$ & 6.5 & 92 & 41 & -70 & 8 & 1.3 & 0.4 \\
\hline MAHO & 39.8959 & 4.2665 & $25 / 05 / 2001$ & $00: 40: 50$ & 6.6 & 90 & 25 & -59 & 20 & 1.7 & 0.9 \\
\hline MAHO & 39.8959 & 4.2665 & $02 / 12 / 2001$ & $13: 01: 53$ & 6.5 & 92 & 32 & -78 & 6 & 1.7 & 0.4 \\
\hline MAHO & 39.8959 & 4.2665 & $18 / 12 / 2001$ & 04:02:58 & 6.8 & 94 & 54 & 71 & 17 & 1.6 & 0.8 \\
\hline MAHO & 39.8959 & 4.2665 & $26 / 03 / 2002$ & $03: 45: 48$ & 6.6 & 96 & 53 & 76 & 10 & 1.0 & 0.3 \\
\hline MAHO & 39.8959 & 4.2665 & $18 / 06 / 2002$ & $13: 56: 22$ & 6.6 & 99 & 238 & -77 & 10 & 0.7 & 0.2 \\
\hline MAHO & 39.8959 & 4.2665 & $27 / 06 / 2002$ & $05: 50: 35$ & 6.9 & 102 & 89 & null & & & \\
\hline MAHO & 39.8959 & 4.2665 & $03 / 10 / 2002$ & $16: 08: 29$ & 6.5 & 91 & 302 & -66 & 12 & 2.5 & 0.3 \\
\hline MAHO & 39.8959 & 4.2665 & $15 / 11 / 2002$ & $19: 58: 31$ & 6.6 & 102 & 202 & -89 & 10 & 0.7 & 0.2 \\
\hline MAHO & 39.8959 & 4.2665 & $27 / 01 / 2003$ & $17: 56: 25$ & 6.5 & 90 & 159 & 52 & 6 & 1.4 & 0.2 \\
\hline MAHO & 39.8959 & 4.2665 & $17 / 03 / 2003$ & $16: 36: 17$ & 6.8 & 89 & 4 & null & & & \\
\hline GRI & 38.8221 & 16.4200 & $25 / 07 / 2004$ & $14: 35: 19$ & 6.8 & 90 & 93 & 39 & 11 & 1.3 & 0.8 \\
\hline GRI & 38.8221 & 16.4200 & $17 / 03 / 2004$ & $03: 21: 07$ & 6.3 & 97 & 249 & 16 & 7 & 2.3 & 0.2 \\
\hline VENT & 40.7948 & 13.4216 & $17 / 03 / 2004$ & $03: 21: 07$ & 6.3 & 97 & 247 & -86 & 5 & 2.0 & 0.2 \\
\hline VENT & 40.7948 & 13.4216 & $19 / 05 / 2004$ & 07:04:11 & 6.1 & 91 & 61 & -69 & 6 & 1.7 & 1.1 \\
\hline VENT & 40.7948 & 13.4216 & $29 / 06 / 2004$ & 07:01:30 & 6.3 & 93 & 285 & 79 & 6 & 1.7 & 0.4 \\
\hline VENT & 40.7948 & 13.4216 & $25 / 07 / 2004$ & $14: 35: 19$ & 6.8 & 90 & 91 & -58 & 4 & 2.3 & 0.2 \\
\hline TIP & 39.1794 & 16.7583 & $29 / 05 / 2004$ & $20: 56: 09$ & 6.6 & 91 & 43 & 2 & 10 & 1.4 & 0.2 \\
\hline TIP & 39.1794 & 16.7583 & $22 / 07 / 2004$ & $09: 45: 14$ & 6.1 & 89 & 56 & 18 & 16 & 1.9 & 0.9 \\
\hline TIP & 39.1794 & 16.7583 & $25 / 07 / 2004$ & $14: 35: 19$ & 6.8 & 90 & 94 & 31 & 4 & 1.3 & 0.1 \\
\hline TIP & 39.1794 & 16.7583 & $07 / 08 / 2004$ & $09: 30: 16$ & 6.3 & 88 & 2 & null & & & \\
\hline SOI & 38.0732 & 16.0542 & $19 / 05 / 2004$ & 07:04:11 & 6.1 & 91 & 63 & 36 & 9 & 2.0 & 1.2 \\
\hline SOI & 38.0732 & 16.0542 & $25 / 07 / 2004$ & $14: 35: 19$ & 6.8 & 90 & 93 & 37 & 9 & 1.1 & 0.3 \\
\hline CUC & 39.9938 & 15.8155 & $29 / 05 / 2004$ & $20: 56: 09$ & 6.6 & 91 & 42 & -5 & 6 & 2.3 & 0.6 \\
\hline CUC & 39.9938 & 15.8155 & $19 / 05 / 2004$ & 07:04:11 & 6.1 & 91 & 63 & -16 & 5 & 2.5 & 0.8 \\
\hline CUC & 39.9938 & 15.8155 & $25 / 07 / 2004$ & $14: 35: 19$ & 6.8 & 90 & 93 & null & & & \\
\hline CUC & 39.9938 & 15.8155 & $07 / 08 / 2004$ & $09: 30: 16$ & 6.3 & 88 & 1 & null & & & \\
\hline CEL & 38.2603 & 15.8939 & $29 / 05 / 2004$ & $20: 56: 09$ & 6.6 & 91 & 42 & 1 & 18 & 2.2 & 0.9 \\
\hline CEL & 38.2603 & 15.8939 & $22 / 07 / 2004$ & $09: 45: 14$ & 6.1 & 89 & 56 & 10 & 10 & 1.4 & 0.3 \\
\hline CEL & 38.2603 & 15.8939 & $25 / 07 / 2004$ & $14: 35: 19$ & 6.8 & 90 & 93 & 25 & 3 & 1.4 & 0.2 \\
\hline
\end{tabular}

The five null measurements are not plotted in the figures.

interpret these features as related to different sequential phases of the Tertiary tectonic evolution of the region.

- Around the Liguro-Provençal area (Fig. 3) the splitting measurements evidence a smoothly rotating direction pattern, in clear continuity from the southern Massif Central ( $\phi \sim$ NW-SE) through the Gulf of Lion, in SE France, to the Balearic Islands, where $\phi$ display a more ENE-WSW direction, to the CorsicaSardinia block where fast directions $\phi$ become definitively E-W [25]. We relate this feature to the formation of the Liguro-Provençal basin, which took place since Oligocene (30 Ma) through a rifting episode along the present location of Gulf of Lion induced by the subduction of African oceanic lithosphere under the European margin [10]. The rollback of the slab induced a back-arc extension accompanied by a relatively fast (3-4 cm/yr) [29] episode of oceanic spreading and by a $30^{\circ}$ counter-clockwise rotation of the Corsica-Sardinia-Calabria block on the hangingwall of the subduction [7]. The southeastward migration of subduction in this phase, which lasted to about $16 \mathrm{Ma}$ [30], has left clear traces of flow in the asthenospheric mantle around the Liguro-Provençal basin [22].

- In the whole Tyrrhenian domain, the anisotropy fast directions display $\mathrm{W}-\mathrm{E}$ prevalent directions and maintain this constant orientation from the SardiniaCorsica block to the western coast of the Italian peninsula (Fig. 3). This trend can be associated with the new extensional episode which began in the Tortonian $(\sim 10 \mathrm{Ma})$, after the termination of the 
drifting and oceanic spreading in the Liguro-Provençal area marked by the end of the Corsica-Sardinia block rotation [30]. This second lithospheric rifting separated Calabria from the Corsica-Sardinia block causing the opening of the southern Tyrrhenian basin in a roughly $\mathrm{W}-\mathrm{E}$ direction [29]. The frozen mantle flow direction retrieved from seismic anisotropy closely matches the direction of maximum extension in the basin (Fig. 1) and evidences the primary role of the rollback motion of what is now the remnant of the African oceanic lithosphere-the Tyrrhenian slab. - Approaching the Apennines, the fast splitting axes abruptly change direction and become parallel to the mountain belt, following its curvature from NNWSSE in the north, to N-S and to NE-SW in the farther south Calabria (Fig. 3). We interpret this complicate mantle flow pattern in the light of the most recent stage of the subduction evolution. After the drifting and the arching of the Calabria block to the present-day position, the final tectonic episodes, which led to the exposure of the accretionary wedge and to the present configuration of the Apenninic belt, are likely governed by the occurrence of a slab fragmentation processes in response to the heterogeneous nature (continental or oceanic) of the lithosphere entering in the mantle along the Apenninic margin [10]. These processes resulted in the formation of the narrow slab beneath the southern Tyrrhenian [10,31], where the long route of subduction across the Mediterranean mantle reached its current destination.

\section{Anisotropy vs. tomography: a time-integrated history of subduction in the western-central Mediterranean}

By integrating independent data sets that were already published and that converge toward similar interpretations [22-25] we obtain a coherent pattern of anisotropy that illustrates an example of slab rollback from its initiation point to its present-day position. A further crucial step is the comparison between complementary data such as $P$-wave velocity anomalies that may give information on where the slab and the deep lithospheric roots are located (a snapshot on the present-day mantle structure) and SKS splitting that provide a mapping of the upper mantle strain (a time-integrated history of mantle flow); such a comparison can corroborate the hypothesis that the evolution of the subduction process and the development of the mantle circulation in the western-central Mediterranean are tightly bound. To this scope we superim- pose the splitting measurements to the tomographic image [12] of the study area at $150 \mathrm{~km}$ depth (Fig. 4). At this depth, subduction appears to be fragmented: remnant of the once continuous slab (fast velocity anomalies) are clearly detected beneath the northern Apennines, the Calabrian arc, and the Maghrebides. Obviously, a direct analysis of the relationship between subduction and anisotropy parameters is possible only in areas where splitting measurements (green bars on Fig. 4) are present and concurrently tomography is able to retrieve the subduction signatures. Thus it is straightforward to observe that fast directions map return flow trajectories just around the western edge of the present-day Tyrrhenian slab, depicting a ring around Sicily [24] and reproducing the results of laboratory experiments in the case of trench migration and rollback sinking of oceanic plates [32]. In northern Apennines, the location of fast velocity perturbation reflects a sudden change in the splitting directions, from trench-perpendicular in the fore slab to trench-parallel in the retro slab mantle [23]. These observations demonstrate that the plate-to-plate interaction at the trench has crucial repercussions in the mantle flow pattern, as the main changes in the anisotropy directions and delays occur in correspondence of the recently (central Apennines) and currently (northern Apennines and Calabrian arc) subducting lithosphere as seen by tomography $[11,12]$.

To obtain an evenly spaced representation of the mantle strain and to highlight large-scale patterns in the study area, we interpolate the fast splitting directions using a smoothing algorithm [33] which averages at least five neighbour measurements on a searching radius $(A)$ over a regular grid, using a tricubic distance weight function. We first apply it to a $0.5^{\circ}$ (lat) $\times 0.5^{\circ}$ (lon) grid with $A=60 \mathrm{~km}$, roughly corresponding to the radius of the Fresnel zone of $S K S$ waves $(T=10 \mathrm{~s})$ at $150 \mathrm{~km}$ depth. This allows us to filter out local, shortscale perturbations within the observed fast orientations and to highlight their general trend in well-sampled regions (black solid bars in Fig. 4). We then obtain a simplified picture of the anisotropy directions, rotating from E-W below the Pyrenees, to NW-SE in the Massif Central and south-eastern France, to N-S beneath the western Alps. The anisotropy pattern in the southern Massif Central and in the south-eastern France is hardly compatible with lithospheric structures related to the Hercynian orogeny [22], as evidenced for the Pyrenees [20,21], but rather suggests that the southeastward rollback of the slab has indeed affected the mantle flow, possibly channelled and deflected by the deep lithospheric roots of the Alps [25]. The continuity 

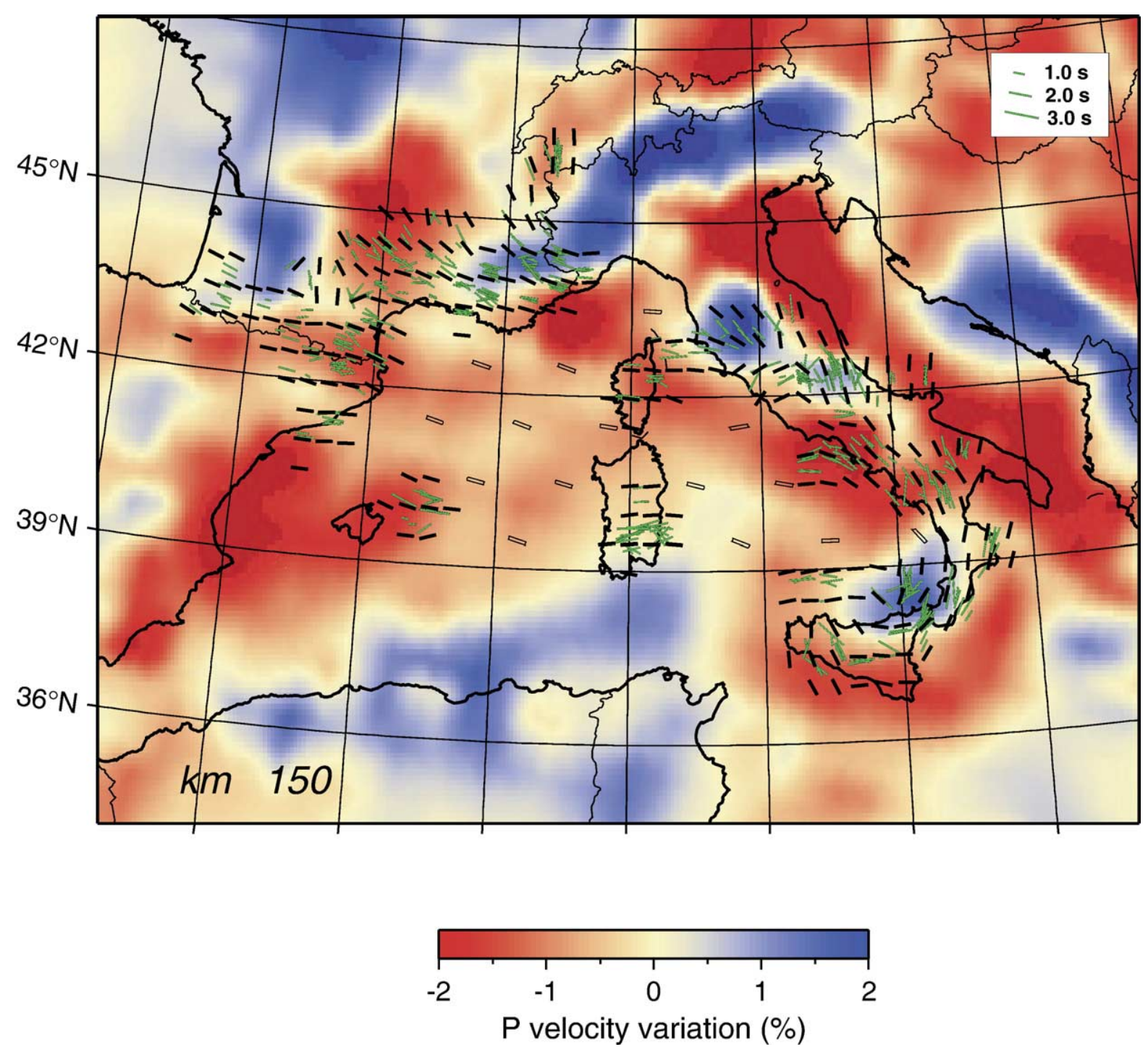

Fig. 4. Comparison between $P$-wave velocity anomalies at $150 \mathrm{~km}$ depth [12] and $S K S$ splitting measurements of Fig. 3 (green bars) in the westerncentral Mediterranean area: tomography reveals the mantle deep structures and anisotropy marks the mantle strain. A continuous representation of the horizontal mantle deformation pattern in the study region has been obtained by smoothing the raw splitting data beneath well sampled areas (solid black bars) and extrapolating fast directions beneath the marine basins (empty bars). We use a power distance weight function [33] over a 60$\mathrm{km}$ radius on a grid of $0.5^{\circ}$ (lat) $\times 0.5^{\circ}$ (lon) in the first case, and over a $250-\mathrm{km}$ radius on a grid of $2^{\circ}$ (lat) $\times 2^{\circ}$ (lon) for the extrapolated directions.

of trench-parallel splitting pattern is enhanced all along the Apennines, where it possibly reflects the presence of strained material in the sublithospheric mantle as a consequence of pressure induced by the slab retrograde motion (i.e. [32,34]). Clearly, the occurrence of preexisting frozen anisotropies in the thinned Apennine lithosphere and in the Adriatic-Ionian subducting lithospheric mantle [35], or alternative mechanisms in

Fig. 5. Three-dimensional cartoons showing the Tyrrhenian subduction (blue areas) at various stages of its evolution, from 30 Ma (a) to the present (d). See text for interpretation. Coastlines are yellow. Red arrows represent the 3D mantle flow induced by the slab rollback process. Light red arrow symbolizes the hot mantle plume upwelling beneath the Massif Central (France) during Miocene time. Blue arrow indicates the direction of subduction. Dashed areas are old (thicker hatching) and new formed (lighter hatching) oceanic basins. Bricks-like fillings stand for continental lithosphere. The Corsica-Sardinia and Calabria blocks are small squares filled. Line with the sawtooth pattern indicate trench which is black where the subducting slab is considered to be continuous up to the surface, while it is grey where slab is assumed to be detached. To get the reader properly oriented through the 3D drawings, an inset showing exactly the same map used for the top layer of each block diagram, is plotted with the usual orientation ( $\mathrm{N}$ towards top). Red arrows on the insets sketch the horizontal asthenospheric flow. 

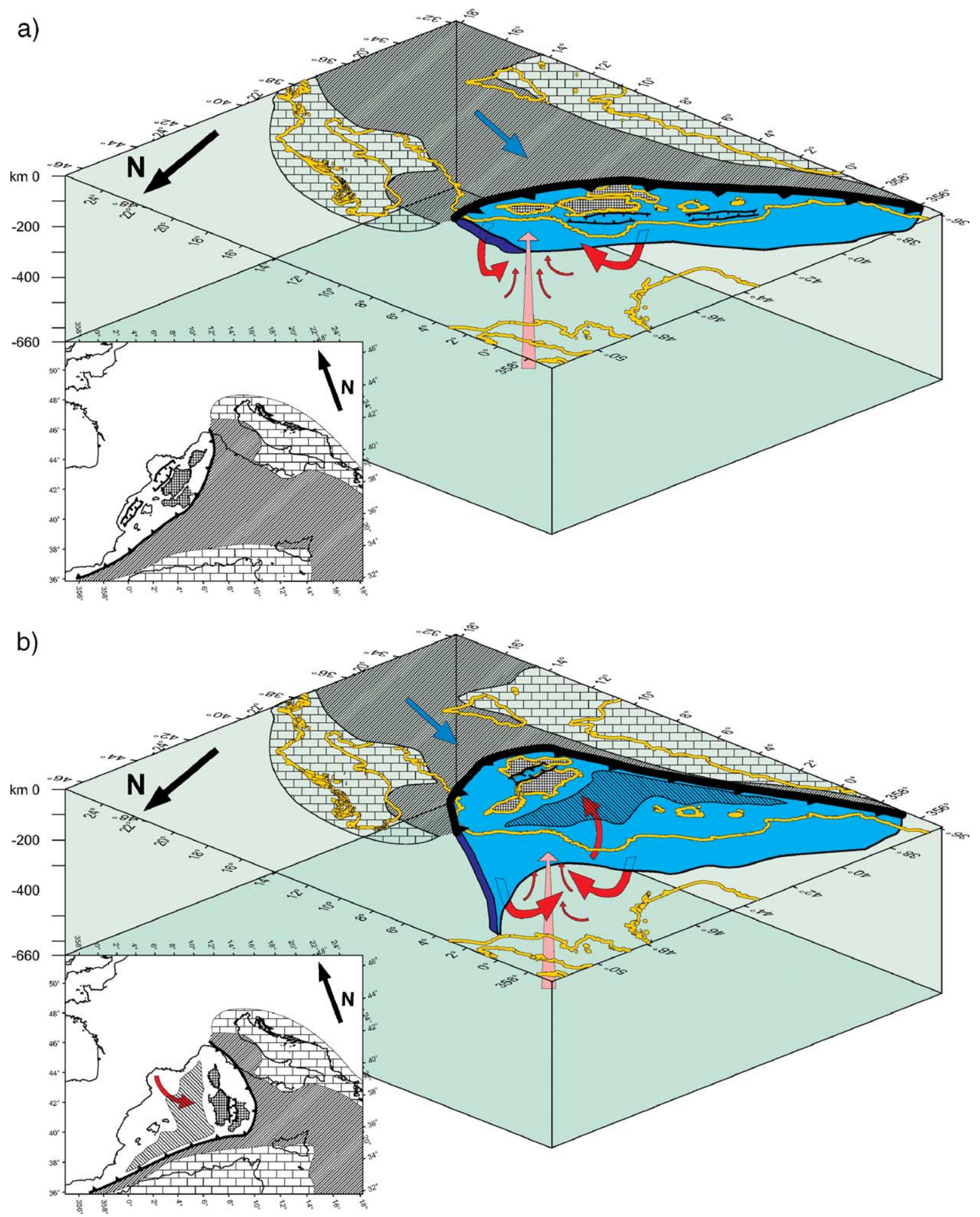

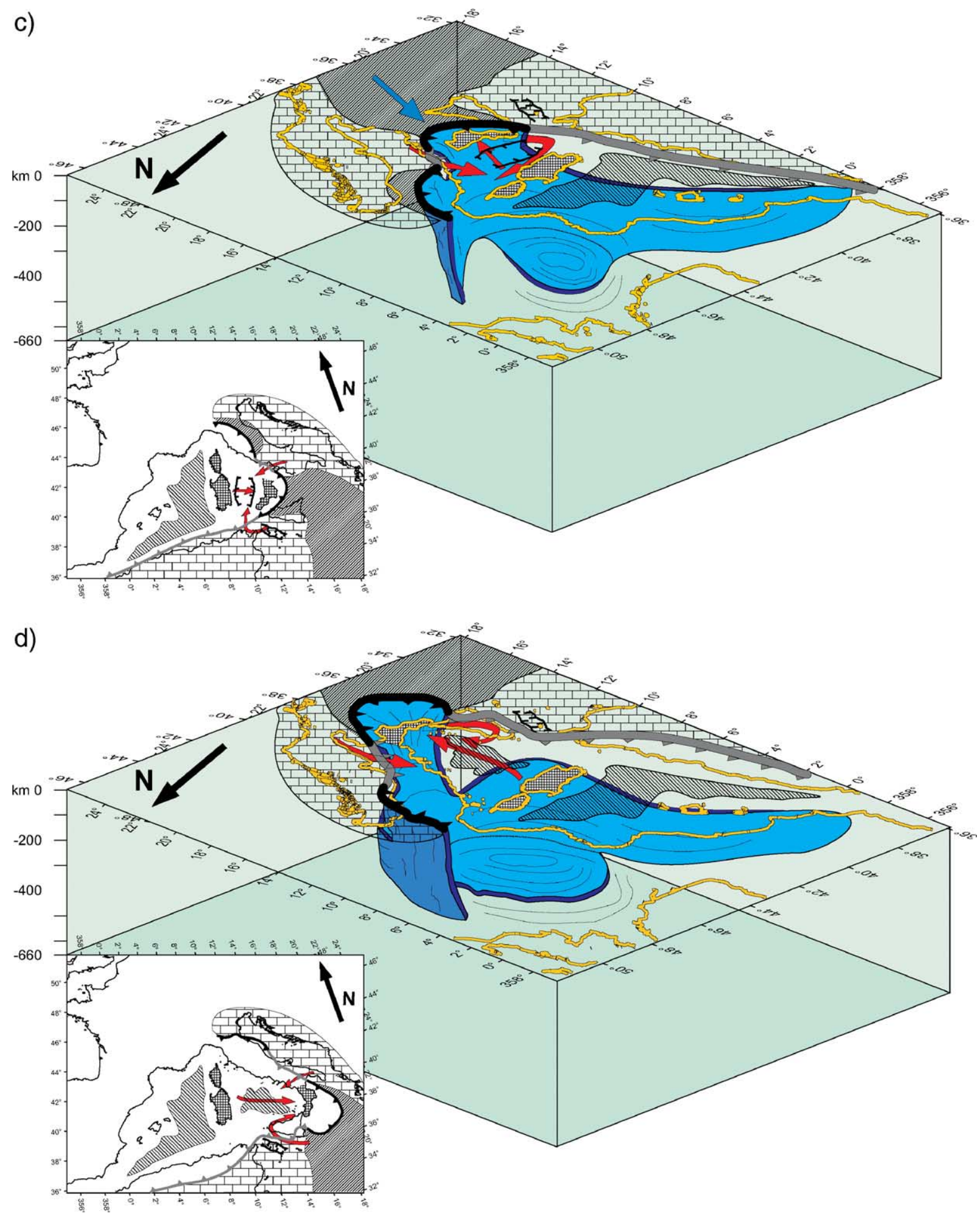

Fig. 5 (continued).

generating seismic anisotropy, such as in high stress or high water content environment [36], cannot be completely ruled out.
We further apply the smoothing on a larger grid of $2^{\circ}$ (lat) $\times 2^{\circ}$ (lon), with $A=250 \mathrm{~km}$ to extrapolate splitting directions (empty bars in Fig. 4) in areas where we 
have no observations to constrain the model, namely in the inner parts of the marine basins where the signature of the extensional tectonics should be dominant and fast direction should image the "frozen-in" or the presentday mantle flows. Although such large-scale extrapolation cannot compensate the lack of measurements beneath the ocean basins, it provides a flow model that could be tested in the future for instance by deploying OBS. Overall, the extrapolated (empty bars) mantle flow configuration in the western-central Mediterranean basin, together with the smoothed measurements pattern (solid bars) in the surrounding areas, follow the displacement trajectories related to back-arc extension (see Fig. 1) [10], suggesting that the opening of the basins and the mantle flow detected by anisotropy can be regarded as the manifestations of an unique phenomenon: the sinking and the rollback of the subducting Tyrrhenian slab.

\section{Toward a 3D interpretative model of mantle flow in the western-central Mediterranean}

In the framework where we move our interpretations, i.e. that seismic anisotropy is representative of the upper mantle flow, the compilation of such a comprehensive map of fast split shear waves orientation in the western-central Mediterranean and the translation of the anisotropic strength and orientation into a regional map of shallow-mantle convective motions rises important considerations and offers possible answers to some debated questions: What drives geodynamics in western-central Mediterranean? What determines the direction and intensity of mantle flow in this area? Why, while Europe and Africa slowly converge in N-S direction, newly formed oceanic basins open in a roughly $\mathrm{W}-\mathrm{E}$ direction and at much faster rates than the two macro-plates approaching motion?

Besides local scale variations, the map of the anisotropy parameters in western-central Mediterranean (Fig. 3) shows an overall coherent pattern which is hardly compatible with an asthenospheric flow primarily related to the protracted (from late Cretaceous) motion of Africa toward the Eurasian plate, likely resulting in a general N-S trend of fast directions $\phi$. As matter of fact, over the past $80 \mathrm{My}$, Africa has been slowly converging toward stable Eurasia-at about $1-2 \mathrm{~cm} \mathrm{yr}^{-1}$ on average-on a NNE path until about $40 \mathrm{Ma}$, then on a northerly path, and finally rotating to a $\mathrm{N} 20^{\circ} \mathrm{W}$ convergence, causing the orogenic Alpine build-up as well as the consumption of most of the former Tethys ocean [29]. Instead, the geometry of mantle flow retrieved by seismic anisotropy suggests a straightforward relation- ship between anisotropy and subduction in this area: the dynamics of the Tyrrhenian slab seem to have governed the regional mantle circulation, leaving clear traces of its motion all along its retreating route.

The sinking of the slab and its progressive migration toward its current position may have induced a NW-SE pressure gradient within the asthenosphere responsible for the observed mantle flow beneath the whole western-central Mediterranean area. In other words a channelled asthenospheric flow from NW would have been pulled by the southeastward rollback of the slab in order to fill the space left behind the subducting and retreating lithosphere. Such a flow has likely been preserved in the upper mantle and may dominate the present-day observed anisotropy [22], given that no other relevant tectonic and/or thermal episode-at the same strength and spatial scale-occurred in the subsequent time [37].

Since mass conservation requires that mantle displaced from the ocean side of the plate moves toward the edges, either around or beneath the sinking plate, and since these two options would not evenly suit the Tyrrhenian slab whole evolution, we need to explain the origin of the mantle material strained in the rollback direction during its various stages. To do this we combine the interpretation given in previous papers for the seismic anisotropy pattern around the Liguro-Provençal $[22,25]$ and the Tyrrhenian $[23,24]$ areas with the recent results of laboratory model on three dimensional mantle circulation in case of rollback subduction $[32,38]$ in the following scenario:

At the initiation time of the first rifting-drifting episode (Fig. 5a), which led to the opening of the Liguro-Provençal basin (30 Ma), the western Mediterranean subduction zone was probably continuous and extended for about $1500 \mathrm{~km}$ from the Gibraltar region to the western Alps $[7,8,10]$. In this phase, it's unlikely that material coming from around the edge of the slab could have reached the loci where we have mapped the seismic anisotropy. As shown by Kincaid and Griffiths [32], during these early stages of subduction, material from the ocean side of the plate can move under the plate's tip. Alternatively, it has been proposed by Barruol and Granet [22] that the hot and low viscous ascending mantle beneath the Massif Central, related to the plume upwelling [39], could have been pulled and deflected toward the SE between the Pyrenean and Alpine lithospheric roots by the rollback suction and could therefore explain the anisotropy pattern observed in southern France. Such asthenospheric flow beneath southern France is not in contradiction with an Hercynian, lithospheric, anisotropy beneath the Pyrenees 
[20,21]. As already proposed by Barruol et al. [21], both the Hercynian structure and the extension-related Tertiary deformation may be present in the upper mantle, particularly in the eastern part of the belt. Obviously the plume upwelling may have locally enhanced the transfer of material from below the slab (Fig. 5a,b) and amplified the shearing effect exerted by the rollback suction on the upper mantle.

The end of this first extensional phase (16-15 Ma) coincides with, and is possibly caused by, the slab arrival at the $660 \mathrm{~km}$ discontinuity (Fig. 5b) [29]. Around 12-10 Ma, the locus of extension jumps southward to the Tyrrhenian basin, and the second riftingdrifting episode begins (Fig. 5c). From this moment onward, the transfer of mantle material from beneath is prevented by the slab lying flat on the upper-lower mantle discontinuity (cfr. Fig. 2), and the unique wedge feeding mechanism becomes the flow of material from around the edges of the plate $[32,38]$. At the same time, the eastward retreat of the slab to its current position beneath the Calabrian arc (Fig. 5d) can be achieved only if the plate is deformed enough (creating an arc and opening slab windows) to permit the lateral escape of sub-slab material $[10,38]$. As a matter of fact, the narrow lateral extent of the present-day Tyrrhenian subduction, as defined by seismicity [9] and imaged by tomography [11-13], argues for the occurrence of episodes of lateral slab fragmentation that governed the last evolutionary stages of the western Mediterranean subduction zone. Slab windows opened along the Sicily channel and below the southern Apennines, respectively to the south [10] and north [40] of the current southern Tyrrhenian slab. This created two natural pathways for the mantle material to go from behind the slab, around the edges of the plate and toward the inner Tyrrhenian basin (Fig. 5c,d). The reliability of this mantle circulation mechanism is proved by the observed anisotropy around the present-day Calabrian slab [24], which matches models of return flow trajectories obtained in laboratory experiments in case of retreating, laterally unconstrained, slab $[32,38]$.

We have then obtained a picture of the westerncentral Mediterranean as a plate convergent environment where the gravity-controlled sinking of a cold, denser oceanic slab into the subduction zone and its rollback have to be considered as the major force acting in the system in the last $30 \mathrm{My}$, responsible for the stretching of the overriding plate and the formation of new oceanic lithospheres.

By reconciling the anisotropy observations with the tomographic geometry of the Tyrrhenian slab, we gain insights into the mantle circulation in the area, which seems to have developed in a regional convective cell driven by a rollback process and evolved in a regime of restricted mantle circulation. Therefore, we identify in the feedback mechanism between subduction and triggered mantle flow the principal cause of the fast tectonic evolution in the western-central Mediterranean system.

The data we show add another piece to the puzzling geodynamic history of the Mediterranean area: the hypothesis that western-central Mediterranean was mainly shaped by the southeastern migration of the slab, proposed by many authors on the bases of various kinds of geological and geophysical observables, finds here a further strong supporting evidence.

\section{Acknowledgments}

We are grateful to the GEOFON program of GFZ Potsdam for the data at the Balearic Islands. Data from southern Italy are provided by MEDNET and RSNC networks of INGV. We thank Birgit Müller for the code used to interpolate fast directions [33]. Manuscript benefited by the comments of M. Savage and an anonymous reviewer. We use GMT software [41] to prepare maps.

\section{References}

[1] J.F. Dewey, M.L. Helman, E. Turco, D.W.H. Hutton, S.D. Knott, Kinematics of the western Mediterranean, in: M.P. Coward, D. Dietrich, R.G. Park (Eds.), Alpine Tectonics, Geol. Soc. London, Spec. Publ., vol. 45, 1989, pp. 265-283.

[2] S. Rebaï, H. Philip, A. Taboada, Modern tectonic stress field in the Mediterranean region: evidence for variations in stress directions at different scales, Geophys. J. Int. 110 (1992) $106-140$.

[3] J. Dercourt, L.P. Zonenshain, L.E. Ricou, Geological evolution of the Tethys belt from the Atlantic to the Pamir since the Lias, Tectonophysics 123 (1986) 241-315.

[4] B. Durand, A. Mascle, L. Jolivet, F. Horvàth, M. Séranne (Eds.), The Mediterranean Basins: Tertiary Extension Within the Alpine Orogen, Geol. Soc. London, Spec. Publ., vol. 156, 1999.

[5] L. Jolivet, C. Faccenna, Mediterranean extension and the Africa-Eurasia collision, Tectonics 19 (2000) 1095-1107.

[6] A. Malinverno, W.B.F. Ryan, Extension in the Tyrrhenian Sea and shortening in the Apennines as results of arc migration driven by sinking of the lithosphere, Tectonics 5 (1986) $227-245$.

[7] E. Gueguen, C. Doglioni, M. Fernandez, On the post-25 Ma geodynamic evolution of the western Mediterranean, Tectonophysics 298 (1998) 259-269.

[8] C. Faccenna, T.W. Becker, F.P. Lucente, L. Jolivet, F. Rossetti, History of subduction and back-arc extension in the Central Mediterranean, Geophys. J. Int. 145 (2001) 809-820.

[9] G. Selvaggi, C. Chiarabba, Seismicity and P-wave velocity image of the Southern Tyrrhenian subduction zone, Geophys. J. Int. 122 (1995) 818-826. 
[10] C. Faccenna, C. Piromallo, A. Crespo-Blanc, L. Jolivet, F. Rossetti, Lateral slab deformation and the origin of the western Mediterranean arcs, Tectonics 23 (2004), doi:10.1029/ 2002 TC001488.

[11] F.P. Lucente, C. Chiarabba, G. Cimini, D. Giardini, Tomographic constraints on the geodynamic evolution of the Italian region, J. Geophys. Res. 104 (1999) 20307-20327.

[12] C. Piromallo, A. Morelli, P wave tomography of the mantle under the Alpine-Mediterranean area, J. Geophys. Res. 108 (2003), doi:10.1029/2002JB001757.

[13] M.J.R. Wortel, W. Spakman, Subduction and slab detachment in the Mediterranean-Carpathian Region, Science 290 (2000) $1910-1917$.

[14] W. Ben Ismail, D. Mainprice, An olivine fabric database: an overview of upper mantle fabrics and seismic anisotropy, Tectonophysics 296 (1998) 145-158.

[15] D. Mainprice, G. Barruol, W. Ben Ismail, The seismic anisotropy of the Earth's mantle: from single crystal to polycrystal, in: S.I. Karato (Ed.), Earth's Deep Interior: Mineral Physics and Tomography from the Atomic to the Global Scale, Geodyn. Ser., vol. 117, AGU, Washington DC, 2000, pp. 237-264.

[16] J. Park, V. Levin, Seismic anisotropy: tracing plate dynamics in the mantle, Science 296 (2002) 485-489.

[17] P.G. Silver, Seismic anisotropy beneath the continents: Probing the depths of geology, Annu. Rev. Earth Planet. Sci. 24 (1996) $385-432$.

[18] M.K. Savage, Seismic anisotropy and mantle deformation: What have we learned from shear wave splitting? Rev. Geophys. 37 (1999) 65-106.

[19] W. Ben Ismail, G. Barruol, D. Mainprice, The Kaapvaal craton seismic anisotropy: petrophysical analyses of upper mantle kimberlite nodules, Geophys. Res. Lett. 28 (2001) 2497-2500.

[20] G. Barruol, A. Souriau, Anisotropy beneath the Pyrenees range from teleseismic shear wave splitting, Geophys. Res. Lett. 22 (1995) 493-496.

[21] G. Barruol, A. Souriau, A. Vauchez, J. Diaz, J. Gallart, J. Tubia, J. Cuevas, Lithospheric anisotropy beneath the Pyrenees from shear wave splitting, J. Geophys. Res. 103 (1998) 30039-30054.

[22] G. Barruol, M. Granet, A Tertiary asthenospheric flow beneath the southern French Massif Central indicated by upper mantle seismic anisotropy and related to the west Mediterranean extension, Earth Planet. Sci. Lett. 202 (2002) 31-47.

[23] L. Margheriti, F.P. Lucente, S. Pondrelli, SKS splitting measurements in the Apenninic-Tyrrhenian domain (Italy) and their relation with lithospheric subduction and mantle convection, J. Geophys. Res. 108 (2003), doi:10.1029/2002JB001793.

[24] S. Civello, L. Margheriti, Toroidal mantle flow around the Calabrian slab (Italy) from SKS splitting, Geophys. Res. Lett. 31 (2004), doi:10.1029/2004GL019607.

[25] G. Barruol, A. Deschamps, O. Coutant, Mapping upper mantle anisotropy beneath SE France by SKS splitting indicates a Neogene asthenospheric flow induced by the Apenninic slab rollback and deflected by the deep Alpine roots, Tectonophysics 394 (2004) 125-138.

[26] P.G. Silver, W.W. Chan, Shear wave splitting and subcontinental mantle deformation, J. Geophys. Res. 96 (1991) 16429-16454.

[27] M.K. Savage, A.F. Sheehan, Seismic anisotropy and mantle flow from the great basin to the Great Plains, western United States, J. Geophys. Res. 105 (2000) 13715-13734.

[28] E. Pera, D. Mainprice, L. Burlini, Petrophysical properties of the upper mantle beneath the Torre Alfina area (Northern Apennines, Central Italy), Tectonophysics 370 (2003) 11-30.

[29] C. Faccenna, F. Funiciello, D. Giardini, F.P. Lucente, Episodic back-arc extension during restricted mantle convection in the Central Mediterranean, Earth Planet. Sci. Lett. 187 (2001) $105-116$.

[30] R. Van der Voo, Paleomagnetism of the Atlantic, Tethys and Iapetus Oceans, Cambridge University Press, Cambridge, 1993. $411 \mathrm{pp}$.

[31] G. Rosenbaum, G.S. Lister, Neogene and Quaternary rollback evolution of the Tyrrhenian Sea, the Apennines, and the Sicilian Maghrebides, Tectonics 23 (2004), doi:10.1029/2003TC001518.

[32] C. Kincaid, R.W. Griffiths, Laboratory models of the thermal evolution of the mantle during rollback subduction, Nature 425 (2003) 58-62.

[33] B. Müller, V. Wehrle, S. Hettel, B. Sperner, K. Fuchs, A new method for smoothing orientated data and its application to stress data, in: M.S. Ameen (Ed.), Fracture and In-Situ Stress Characterization of Hydrocarbon Reservoirs, Geol. Soc. London, Spec. Publ., vol. 209, 2003, pp. 107-126.

[34] R.M. Russo, P.G. Silver, Trench-parallel flow beneath the Nazca plate from seismic anisotropy, Science 263 (1994) 1105-1111.

[35] J. Plomerová, V. Babuska, R. Scarpa, Teleseismic P-residual study in the Italian region; inferences on large scale anisotropic structure of the subcrustal lithosphere, Ann. Geophys. 41 (1998) $33-48$.

[36] H. Jung, S. Karato, Water induced fabric transitions in Olivine, Science 293 (2001) 1460-1463.

[37] A. Vauchez, G. Barruol, A. Nicolas, Comment on "SKS splitting beneath rift zones", J. Geophys. Res. 104 (1999) 10787-10789.

[38] F. Funiciello, C. Faccenna, D. Giardini, K. Regenauer-Lieb, Dynamics of retreating slabs: 2. Insights from three-dimensional laboratory experiments, J. Geophys. Res. 108 (2003), doi:10.1029/2001JB00896.

[39] M. Granet, M. Wilson, U. Achauer, Imaging a mantle plume beneath the French Massif Central, Earth Planet. Sci. Lett. 136 (1995) 281-296.

[40] F.P. Lucente, F. Speranza, Belt bending driven by deep processes: geophysical evidences from the northern Apennines (Italy), Tectonophysics 337 (2001) 51-62.

[41] P. Wessel, W.H.F. Smith, New, improved version of Generic Mapping Tools released [version 3.1], EOS Trans. AGU 79 (1998). 